\title{
A tutela jurídica dos refugiados ambientais: o caso haitiano e o sistema interamericano de proteção aos direitos humanos
}

\author{
The legal protection of environmental refugees: \\ the haitian case and the inter-american system \\ of human rights protection
}

CÁtia Rejane Mainardi LicZBinski Universidade Regional de Blumenau - FURB

Leura Dalla Riva Universidade Regional de Blumenau - FURB

Resumo Este artigo aborda a problemática envolvendo a tutela das pessoas deslocadas compulsoriamente, em especial os refugiados ambientais, isto é, aqueles que deixam seu local de origem ou residência em virtude de infortúnios ambientais, como desastres ou mudanças climáticas. Apresenta-se, a título exemplificativo, a realidade vivenciada pelos refugiados haitianos, sobretudo no contexto dos desastres ambientais ocorridos após 2010. Além disso, busca-se averiguar se existe e de que forma ocorre a proteção jurídica dessa categoria, destacando-se o papel desempenhado pelo Sistema Internacional de Proteção dos Direitos Humanos, com foco no Sistema Interamericano.

Palavras-chave: Direitos Humanos. Deslocamento compulsório. ReFUGIADOS AMBIENTAIS. HAITI.

Abstract This article approaches a problematic that involves the guardianship of compulsorily displaced people, especially the environmental refugees, that is, those who leave their place or origin or residence be- 
cause of environmental misfortunes, as disasters or climate changes. It is presented, as an example, the reality lived by Haitian refugees, especially in the context of environmental disasters that happened after 2010. In addition, it's sought to ascertain if legal protection of this category occurs and how, highlighting the role played the International System of Protection of Human Rights, focusing on the Inter-American System.

Keywords: Human Rights. Compulsory Displacement. EnvironmenTAL REFUGEES. HAITI.

\section{INTRODUÇÃo}

O crescimento progressivo dos índices de deslocamento humano é característica marcante do início do século XXI, sobretudo no que diz respeito aos movimentos migratórios de natureza involuntária. Como fatores que contribuem para o aumento do deslocamento compulsório pelo globo, destacam-se questões como a facilitação da mobilidade em razão do desenvolvimento tecnológico, a globalização das relações econômicas, além da ocorrência de conflitos armados, tráfico humano e desastres ambientais.

Nesse contexto, a presente pesquisa analisará a tutela jurídica de pessoas deslocadas compulsoriamente em razão de desastres ambientais e alterações climáticas, as quais se enquadrariam na categoria dos refugiados ambientais. Isso porque a situação envolvendo pessoas obrigadas a se deslocar em razão de infortúnios ambientais pode se tornar uma das principais crises vivenciadas pela humanidade, uma vez que o número de indivíduos deslocados de seu local de origem em razão dos efeitos das mudanças climáticas tende a crescer nas próximas décadas.

Sendo assim, busca-se averiguar como ocorre a proteção normativa dos refugiados, em especial dos refugiados ambientais, em âmbito internacional e no ordenamento jurídico brasileiro. Para tanto, este trabalho apresentará a definição e diferenciações necessárias do instituto do refúgio com outras categorias, a evolução histórica e os critérios clássicos utilizados para o reconhecimento do status de refugiado a um indivíduo, analisando também o surgimento de novas hipóteses elenca- 
das por documentos regionais como a Convenção Relativa aos Aspectos Específicos dos Refugiados Africanos adotada pela Organização da Unidade Africana (OUA), a Declaração de Cartagena, de 1984, e a Declaração de São José sobre Refugiados e Pessoas Deslocadas de 1994.

Em seguida, se apresentará o caso dos refugiados haitianos como caso emblemático de refugiados ambientais que, não sendo reconhecidos pelos ordenamentos como tais, dependem da tutela de normas gerais aplicadas a migrantes voluntários e de políticas governamentais humanitárias, como a adotada pelo Brasil, sobretudo após os eventos de 2010, que abalaram a ilha caribenha e proporcionaram o surgimento de uma grande onda de refugiados.

Além disso, a presente pesquisa busca averiguar se o Sistema Internacional de Proteção dos Direitos Humanos, em especial o sistema Interamericano, é uma via possível para que os refugiados ambientais alcancem a proteção de seus direitos e se existem casos envolvendo a temática que já tramitaram na Comissão e Corte Interamericanas.

Quanto à metodologia, destaca-se que o presente artigo está dividido em introdução, três tópicos de desenvolvimento e considerações finais. Para tanto, será utilizado predominantemente o método dedutivo e bibliográfico, proveniente das principais obras doutrinárias referentes ao tema, jurisprudência e legislação pertinente, bem como, artigos e textos jurídicos publicados em revistas especializadas e sítios da internet.

\section{Asilo lato sensu: refúgio}

Os fluxos de deslocamento humano, ao contrário do que se imaginava, após a Segunda Guerra Mundial, aumentaram significativamente no século XXI, sobretudo no que diz respeito às migrações forçadas. Nesse contexto, o presente artigo abordará o enquadramento jurídico dado aos refugiados, em especial os que abandonam seu local de origem em virtude de desastre ou condições ambientais, muitas vezes ocasionados ou impulsionados pelas atividades humanas.

Neste primeiro tópico, analisa-se a definição e evolução histórica do instituto já mencionado, apresentando-se também algumas diferen- 
ciações necessárias à elucidação da temática, em especial, a distinção existente entre o refúgio e as seguintes categorias: asilo político, migração voluntária, apátridas e deslocados internos.

\subsection{A institucionalização do Refúgio}

O Refúgio pode ser considerado espécie de asilo lato sensu e instituto recente do Direito Internacional que visa, em síntese, proteger indivíduos de situações de perseguição.

$\mathrm{O}$ asilo lato sensu teria suas origens na antiguidade clássica grega, época na qual era considerado um instituto pelo qual o indivíduo que sofresse perseguição de seu Estado de origem poderia ser acolhido em outra região. Mais tarde, durante o período medieval, o asilo passou a ser utilizado como mecanismo que, por promover o isolamento da coletividade de determinados grupos de pessoas, visava à extinção desses grupos, a exemplo dos hereges, judeus e leprosos. ${ }^{1}$ Ademais, a secularização do instituto ocorreu apenas após a Reforma Protestante, deixando de ser competência exclusiva da igreja e passando ao Estado. ${ }^{2}$

A consagração do direito de asilo lato sensu ocorreu, sobretudo, por meio da internacionalização dos direitos humanos após a Segunda Guerra Mundial e com a edição da Declaração Universal dos Direitos Humanos de $1948,{ }^{3}$ o que permitiu o acolhimento de estrangeiros que não podiam retornar ao seu local de origem, em razão de perseguição odiosa e sem justa causa, podendo-se dividir em asilo político e refúgio.

1 ANDRADE. José H. F. Breve reconstituição histórica da tradição que culminou na proteção internacional dos refugiados. In: ARAÚJO, Nádia (coord.); ALMEIDA, Guilherme Assis de (coord.). O direito internacional dos refugiados: uma perspectiva brasileira. Rio de Janeiro: Renovar, 2011, p. 106.

2 Tem-se como exemplo a Constituição Francesa de 1793, que instituiu em seu artigo 120 o direito de asilo.

3 Artigo XIV: 1. Todo ser humano, vítima de perseguição, tem o direito de procurar e de gozar asilo em outros países. 2. Este direito não pode ser invocado em caso de perseguição legitimamente motivada por crimes de direito comum ou por atos contrários aos objetivos e princípios das Nações Unidas (ONU, 1948). 
Por hora, mostra-se suficiente estabelecer que o instituto do refúgio é espécie de asilo lato sensu assim como o asilo político, mas com este não deve ser confundido. Isso porque o instituto do Refúgio não é ato discricionário do Estado concessor, mas dever de proteção vinculada ao preenchimento de hipóteses legalmente determinadas.

Com efeito, o asilo político se divide em diplomático e territorial ${ }^{4}$ e pode ser definido como "a recepção de estrangeiro, em um Estado diverso de sua nacionalidade, perseguido em decorrência de desavenças políticas, de delitos de opinião, bem como, de violação de normas não incluídas nos parâmetros do direito penal comum", podendo ser considerado como uma faculdade do Estado concedente e destinado exclusivamente aos indivíduos que sofram ataques por razões políticas. ${ }^{5}$

Assim, enquanto o asilo político trata de hipóteses discricionárias de concessão, limitadas a questões políticas e ancoradas em uma perseguição existente, o Refúgio abrange hipóteses legalmente definidas, apoiadas essencialmente em um fundado temor de perseguição, por motivos de opinião política, raça, religião, nacionalidade ou pertencimento a determinado grupo social. Vale ressaltar, todavia, que ambos os institutos têm como fundamento a solidariedade e cooperação internacionais e possuem caráter humanitário, pois visam à proteção da pessoa humana, a fim de assegurar e garantir os requisitos mínimos de vida e de dignidade.

Apresentada essa diferenciação inicial entre citados institutos, a qual será abordada especificamente mais adiante, passa-se à análise pontual do refúgio.

4 O asilo territorial não pode ser confundido com o asilo diplomático, podendo ser definido como a proteção dada por um Estado, em seu território, a uma pessoa cuja vida ou liberdade se acha ameaçada pelas autoridades de seus países, em virtude de ser acusado por violações a sua lei penal ou, geralmente, por ter deixado o seu país para se livrar de perseguição política. SILVA, Geraldo Eulálio do Nascimento. Os refugiados políticos e o asilo territorial. In: ARAÚJO, Nádia (coord.); ALMEIDA, Guilherme Assis de (coord.) (Op. cit. p. 11).

5 SERRAGLIO, Diogo Andreola. A proteção dos refugiados ambientais pelo direito internacional: Uma leitura a partir da Teoria da Sociedade de Risco. Curitiba: Juruá, 2014, p. 70. 
Em que pese à temática relativa aos refugiados existir desde o século XV, o refúgio se estabeleceu como instituto em 1921, tendo como marco a Liga das Nações, diante do grande contingente de refugiados perseguidos pela URSS. ${ }^{6}$ Além disso, o refúgio só foi regulamentado em 1951 com a elaboração, pela recém-criada Organização das Nações Unidas - ONU - de um órgão de caráter universal que tutelasse refugiados, dando origem ao Alto Comissariado das Nações Unidas para Refugiados - ACNUR. Assim, as primeiras políticas internacionais no âmbito da proteção de pessoas deslocadas forçadamente de seu país de origem surgiram somente após a Segunda Guerra Mundial, sobretudo por meio da criação do ACNUR pela Convenção de 1951 (revisada posteriormente pelo Protocolo de 1967).

Atualmente, o ACNUR assiste qualquer pessoa que se encontre fora de seu país de origem e não pode ou não quer regressar ao mesmo "por causa de fundados temores de perseguição devido à sua raça, religião, nacionalidade, associação a determinado grupo social ou opinião política $[. .$.$] conflitos armados, violência generalizada e violação mas-$ siva dos direitos humanos".?

Todavia, em que pesem as medidas adotadas pela Organização das Nações Unidas, o número de deslocamentos forçados chegou, até o final de 2015, ao total de 65,3 milhões de pessoas, incluídas entre elas: 21,3 milhões de refugiados, 3,2 milhões de solicitantes de refúgio e 40,8 milhões deslocados internos. ${ }^{8}$

\footnotetext{
Segundo Jubilut: “[...] o instituto do refúgio surge apenas no início do século XX, sob a égide da Liga das Nações, em face de um contingente elevado de pessoas perseguidas na União das Repúblicas Socialistas Soviéticas. Para as quais seria impossível uma qualificação individual, por meio do instituto do asilo, dado que nenhum Estado estaria disposto a, discricionariamente, acolher milhares de pessoas, sendo necessária uma qualificação coletiva que lhes assegurasse a proteção internacional". JUBILUT, Liliana Lyra. O direito internacional dos refugiados e sua aplicação no ordenamento jurídico brasileiro. São Paulo: Método, 2007, p. 44.

7 ALTO COMISSARIADO DAS NAÇÕES UNIDAS PARA REFUGIADOS. Breve histórico do ACNUR. Disponível em: <http://www.acnur.org/portugues/informacao-geral/breve-historico-do-acnur/>. Acesso em 05/12/2017.

8 Dados fornecidos pelo relatório anual "Tendências Globais" ("Global Trends"), que registra o deslocamento forçado ao redor do mundo com base em dados dos governos, de agências parceiras e do Alto Comissariado das Nações Unidas para Refugiados - ACNUR.
} 


\subsection{Outras categorias de deslocamento humano e dife- renciações necessárias}

Antes de iniciar a abordagem legislativa do instituto do Refúgio e as hipóteses que podem ensejar a concessão do status de refugiado a um indivíduo, mostra-se importante estabelecer as diferenças existentes entre o instituto do refúgio e as seguintes categorias: migração voluntária, asilo político (territorial e diplomático) e deslocados internos.

Como exposto inicialmente, o instituto do refúgio é espécie de asilo lato sensu assim como o asilo político, mas ambos os institutos não podem ser tidos como sinônimos. Conforme nos ensina Serraglio, ${ }^{9}$ o asilo político é regulado, sobretudo, pelo costume internacional e pelos tratados regionais firmados em cada continente, possuindo campo de abrangência e tutela mais restritos que o instituto do Refúgio, o qual teria alcance universal, uma vez que sua proteção emana de órgão pertencente à Organização das Nações Unidas.

Além disso, o asilo político limita-se à proteção de perseguição política e é pautado na urgência, enquanto o refúgio tutela a própria ameaça de perseguição em cinco modalidades que podem ensejar o reconhecimento do status de refugiado a um indivíduo, hipóteses essas que serão analisadas detalhadamente no tópico seguinte.

Oportuno observar que, para que haja a configuração do refúgio, é imprescindível que o sujeito esteja fora de seu território de origem ou nacionalidade, requisito que não se exige do asilado político ${ }^{10}$ (diplomático). Contudo, vale frisar novamente que tanto o asilo político quanto o refúgio são institutos de caráter humanitário e carregam em seu fundamento a solidariedade e cooperação internacionais, visando à proteção da pessoa humana, a fim de assegurar a dignidade humana.

\footnotetext{
SERRAGLIO, Diogo Andreola. Op. cit. p. 87.

10 Quanto ao asilo político em si, mostra-se relevante destacar que tal instituto se divide em duas subespécies, sendo elas o asilo diplomático e o asilo territorial, sendo esse concedido quando o solicitante se encontra dentro do território do Estado ao qual solicita proteção e aquele quando o solicitante estiver em extensões do território do Estado solicitado "como, por exemplo, em embaixadas, ou em navios, ou em aviões de bandeira do Estado”. JUBILUT, Liliana Lyra (Op. cit. p. 37).
} 
Jubilut ${ }^{11}$ também observa que ambas as modalidades de asilo político são verificadas principalmente no Direito Internacional Público da América Latina, sobretudo por meio da Declaração Americana dos Direitos e Deveres do Homem (1948) e a Convenção Americana de Direitos Humanos (1969).

Outra diferenciação que se mostra essencial é a que se refere aos migrantes voluntários. Migrante é toda pessoa que se desloca de seu lugar de residência habitual até outro, objetivando se estabelecer em seu destino, de forma permanente ou temporária. Normalmente, o migrante deixa seu país por motivos alheios à sua própria vontade, por exemplo, em virtude de uma guerra, de difíceis condições de vida ou por causa de calamidades. ${ }^{12}$ No entanto, há aqueles que migram voluntariamente rumo a outra localidade pelos mais variados motivos, buscando, geralmente, melhores condições de vida e oportunidades.

Estritamente, o termo "migrante" designa, especialmente, o grupo de pessoas que migram voluntariamente por motivos econômicos, isto é, aqueles que "decidem deslocar-se para melhorar as perspectivas para si mesmos e para suas famílias". ${ }^{13}$ Assim, a migração voluntária diz respeito "àqueles que migram por opção, em busca de melhores condições de vida, para um destino escolhido". ${ }^{14}$ Com efeito, a legislação brasileira, assim como o direito internacional, não considera os migrantes econômicos como refugiados, uma vez que essa categoria seria marcada, essencialmente, pelo aspecto voluntário do deslocamento. ${ }^{15}$

11 IBIDEM.

12 FARENA, Maritza Natalia Ferretti Cisneros. Direitos humanos dos migrantes. Curitiba: Juruá, 2012, p. 29.

13 ALTO COMISSARIADO DAS NAÇÕES UNIDAS PARA REFUGIADOS. Refugiados. Disponível em: <http://www.acnur.org/portugues/quem-ajudamos/refugiados/>. Acesso em 07/10/2017.

14 IDEM, p. 31.

15 O migrante que não se enquadra nas hipóteses de refúgio reconhecidas pelo Brasil, assim, não goza da proteção dispensada ao refugiado e está sujeito à legislação específica, no caso, pelo Estatuto do Estrangeiro (Lei n. 6.815/1980) e pela Lei de Migração (Lei n. 13.445/2017) a partir de novembro de 2017. 
Os fluxos de migração forçada ${ }^{16}$ representam a maioria dos movimentos populacionais da História e se distinguem da migração voluntária em razão do grau de necessidade que força o migrante a abandonar seu local de origem. Para Carolina Claro, os migrantes forçados, ao contrário dos voluntários, não planejam o ato de migrar e costumam manter compromissos no local de origem, pois, em regra, não levam consigo recursos financeiros nem mantêm conexões com o local de destino. ${ }^{17}$

Erika Pires Ramos ${ }^{18}$ salienta que a categoria de migrantes forçados compreenderia refugiados, solicitantes de asilo, deslocados internos, repatriados, reassentados. A autora também destaca o posicionamento de David Turton, segundo o qual o termo "migração involuntária" designaria oposição à "migração voluntária", dando a entender erroneamente que o ato de migrar naqueles casos seria impensado, sugerindo, assim, a adoção do termo "migrações compulsórias".

Nem todo migrante classificado como voluntário migra por livre e espontânea vontade, pois, por vezes, são assim rotulados por não se enquadrarem nas hipóteses legais e clássicas de migração forçada (como asilo e refúgio). Cita-se como exemplo o caso dos refugiados ambientais que, não sendo enquadrados como refugiados pela legislação bra-

16 Ao contrário do que se imaginava após a Segunda Guerra Mundial, os fluxos de deslocamento humano aumentaram significativamente no século XXI, sobretudo no que diz respeito às migrações forçadas. Em que pesem as medidas adotadas pela Organização das Nações Unidas, o número de deslocamentos forçados pelo mundo chegou, até o final de 2015, ao total de 65,3 milhões de pessoas, incluídas entre elas: 21,3 milhões de refugiados, 3,2 milhões de solicitantes de refúgio e 40,8 milhões deslocados internos (Dados fornecidos pelo relatório anual "Tendências Globais", que registra o deslocamento forçado ao redor do mundo com base em dados dos governos, de agências parceiras e do Alto Comissariado das Nações Unidas para Refugiados - ACNUR).

17 CLARO, Carolina de Abreu Batista. Refugiados ambientais: mudanças climáticas, migrações internacionais e governança global. 2012, 113s., il. Dissertação (Mestrado em Desenvolvimento Sustentável) - Universidade de Brasília, Brasília, 2012, p. 34.

18 RAMOS, Érika Pires. Refugiados ambientais: em busca de reconhecimento pelo direito internacional, 2011. Tese (Doutorado em Direito Internacional) - Faculdade de Direito, University of São Paulo, São Paulo, 2011. doi:10.11606/T.2.2011.tde10082012-162021. Acesso em: 2018-02-26, p. 67. 
sileira, são tutelados pelas normas gerais aplicáveis às migrações "voluntárias", ainda que tenham deixado seu país de origem por razões de sobrevivência.

Oportuno destacar também que, em que pese inúmeros apátridas serem enquadrados como refugiados, não se pode confundir as duas categorias. Isso porque o termo apátrida se refere àqueles desprovidos de Estado, ou seja, de nacionalidade. ${ }^{19}$ Nesse contexto, os apátridas se tornaram um grupo vulnerável bastante significativo, sobretudo após o término da Segunda Guerra Mundial, pois, uma vez desprovidos de nacionalidade e cidadania, isto é, conforme ensinamentos de Hannah Arendt, ${ }^{20}$ destituídos do próprio "direito a ter direitos", resta-lhes como alternativa o enquadramento na condição de refugiado. Assim, já que não possuem proteção de qualquer Estado, resta aos organismos e institutos do Direito Internacional tutelar essas pessoas, ainda que por meio do refúgio.

Por sua vez, quanto aos deslocados internos, ${ }^{21}$ tem-se que estes podem ser definidos como pessoas deslocadas dentro do território de

19 A Declaração Universal dos Direitos Humanos da ONU (1948) elenca em seu artigo XV que "Todo homem tem direito a uma nacionalidade" e que "Ninguém será arbitrariamente privado de sua nacionalidade, nem do direito de mudar de nacionalidade", contudo, o ACNUR estima que, embora não se possa auferir com exatidão o número de apátridas existentes, na atualidade, formalmente existiriam cerca de 10 milhões de pessoas em dezenas de países desenvolvidos e em desenvolvimento (ACNUR, 2017d).

20 ARENDT, Hannah. Apud LAFER, Celso. A reconstrução dos direitos humanos: um diálogo com o pensamento de Hannah Arendt. São Paulo: Companhia das Letras, 1988.

21 Segundo dados fornecidos pelo relatório de "Tendências Globais" do ACNUR (2017c)' ao final de 2016, o número de deslocados internos totalizou 40,3 milhões em comparação aos 40,8 milhões no ano anterior, encontrando-se entre os países com maior deslocamento: Síria, Iraque e Colômbia. Além disso, de um total de 65,6 milhões de pessoas que deixaram seu local de origem involuntariamente, contabilizado ao final de 2016, 10,3 milhões representavam pessoas que foram forçadas a se deslocar pela primeira vez e destes, cerca de 6,9 milhões se deslocaram dentro de seus próprios países. Da mesma forma, dados do International Displacement Monitoring Center informam que o conflito, a violência e os desastres ambientais deslocaram internamente cerca de 27,8 milhões de pessoas em 2015, sujeitando um número recorde de homens, mulheres e crianças ao trauma e à agitação dos deslocamentos forçadas dentro do próprio país. 
seu país de origem ou nacionalidade. Esta categoria é, por vezes e de maneira equivocada, confundida com refugiados. ${ }^{22}$ Contudo, ao contrário dos refugiados, os deslocados internos não atravessam fronteiras internacionais, permanecendo em seu país de origem. Assim, ainda que a causa do deslocamento seja semelhante às hipóteses ensejadoras do refúgio, os deslocados internos permanecem sob a tutela do ordenamento pátrio e proteção de seu próprio governo, ainda que este seja a causa do deslocamento. Ademais, mantêm sua condição de cidadãos e todos os seus direitos são protegidos pelo direito dos direitos humanos e o direito internacional humanitário. ${ }^{23}$

Destaca-se que, conforme Serraglio, ${ }^{24}$ "Os deslocados internos representam, então, uma categoria de pessoas que, apesar de não cruzar uma fronteira nacional, se obriga a migrar em razão de agressão, persecução, bem como infortúnios ambientais". Ademais, "grande parte das vítimas de desastres ambientais não deixa seu país de origem, uma vez que visam retornar ao local afetado o mais breve possível”. Assim, o número de deslocados internos supera, amplamente, o de refugiados que se deslocam internacionalmente pelo globo. ${ }^{25}$

\section{LEGISLAÇÃO PROTETIVA EM ÂMBITO INTERNO E INTERNACIO- NAL EM RELAÇÃO AOS REFUGIADOS}

A fim de proporcionar uma abordagem abrangente acerca da tutela dos refugiados e, em especial, dos refugiados ambientais, este trabalho

22 Com efeito, a Convenção das Nações Unidas Relativa ao Estatuto dos Refugiados de 1951 deixou de englobar os indivíduos que, forçadamente, abandonam seu local de origem e permanecem dentro das fronteiras do Estado em que se encontram.

23 ALTO COMISSARIADO DAS NAÇÕES UNIDAS PARA REFUGIADOS. Deslocados internos. Disponível em: < http://www.acnur.org/portugues/quem-ajudamos/ deslocados-internos/ Acesso em: 06/10/2017.

24 SERRAGLIO, Diogo Andreola. Op. cit. p. 101-102.

25 Sobre o tema, também vale destacar o conjunto de Princípios Orientadores Relativos aos Deslocados Internos de 1998, elaborado pela ONU, e a Declaração de São José sobre Refugiados e Pessoas Deslocadas de 1994, que reconheceu que a temática relacionada aos deslocados internos é tema de Direitos Humanos, que deve ser objeto de preocupação da comunidade internacional. 
apresenta a seguir as normas brasileiras e de Direito Internacional aplicáveis ao Refúgio. Além disso, se explanam os critérios clássicos caracterizadores da condição de "refugiado" e o surgimento de novas hipóteses.

Primeiramente, importante relembrar que o refúgio se estabeleceu como instituto apenas em 1921, tendo como marco a Liga das Nações, e só foi regulamentado em 1951 com a elaboração da Convenção Relativa ao estatuto dos Refugiados de 1951, dando origem ao Alto Comissariado das Nações Unidas para os Refugiados - ACNUR, órgão de caráter humanitário, cujas principais funções são proporcionar proteção e propor e implementar soluções para o problema dos refugiados no mundo.

Destaca-se que, no período que antecedeu a criação do ACNUR, criou-se, em 1930, o Escritório Nansen, órgão que se dedicava exclusivamente à questão humanitária dos refugiados, permanecendo sob a direção da Liga das Nações e tendo como principal resultado a Convenção Relativa ao Estatuto Internacional dos Refugiados de 1933 que, em que pese o conteúdo limitado, possibilitou o início da positivação do Direito Internacional dos Refugiados e estabeleceu o princípio do non-refoulement, ${ }^{26}$ que proíbe que indivíduos sejam enviados, contra a sua vontade, para seu território de origem ou outro local no qual possam ser expostos à perseguição ou outro risco.

Com efeito, desde sua configuração, mencionado princípio é de suma importância na tutela dos refugiados ao redor do globo, encontrando-se expressamente previsto pelo artigo 33 da Convenção de 1951 e pelos artigos 36 e 37 do Protocolo de 1967.

Além disso, a Convenção de 1951 foi o primeiro tratado a elencar hipóteses que possibilitariam a concessão do status de refugiado a determinado indivíduo, contudo, em sua versão original, apresentava cláusula de reserva temporal e espacial, limitando-se a tutelar os indivíduos que tiveram de deixar seus locais de origem em virtude de acontecimentos anteriores a $1^{\circ}$. de janeiro de 1951 - Primeira e Segunda Guerra Mundial - e ocorridos no continente europeu:

26 RAMOS, Érika Pires. Op. cit., p. 104. 
Artigo $1^{\circ}$. - Definição do termo "refugiado": A. Para os fins da presente Convenção, o termo "refugiado" se aplicará a qualquer pessoa: [...] 2) Que, em conseqüência dos acontecimentos ocorridos antes de $1^{\circ}$ de janeiro de 1951 e temendo ser perseguida por motivos de raça, religião, nacionalidade, grupo social ou opiniões políticas, se encontra fora do país de sua nacionalidade e que não pode ou, em virtude desse temor, não quer valer-se da proteção desse país, ou que, se não tem nacionalidade e se encontra fora do país no qual tinha sua residência habitual em conseqüência de tais acontecimentos, não pode ou, devido ao referido temor, não quer voltar a ele.

Essa limitação geográfica e espacial se deu porque, à época, acreditava-se que a problemática envolvendo apátridas e refugiados poderia ser solucionada, motivo pelo qual se estabeleceu mandato por prazo determinado ao ACNUR.

Contudo, diante do crescimento incessável dos fluxos de deslocamento humano forçado no século XX, o ACNUR se estabeleceu como órgão permanente e as hipóteses previstas inicialmente pela Convenção de 1951 foram ampliadas pelo Protocolo elaborado em 1967, de modo que a limitação geográfica e temporal foi retirada da definição de refugiado, passando a abranger qualquer pessoa que, temendo ser perseguida por motivos de raça, religião, nacionalidade, grupo social ou opiniões políticas, busca abrigo em outro país.

\subsection{Critérios clássicos para a concessão do refúgio}

Destacam-se como critérios clássicos para a concessão do refúgio a perseguição ou fundado temor de perseguição por motivos de raça, religião, nacionalidade, pertencimento a grupo social ou opiniões políticas. Conforme Jubilut, ${ }^{27}$ "o conceito de raça provém da biologia e tem por fim designar um grupo que apresenta certa homogeneidade no conjunto de aspectos genéticos particulares, hereditariamente transmitidos de geração a geração". Segundo a mesma autora, "foi de uma dessas de-

27 JUBILUT, Liliana Lyra. Op. cit., p. 115-116. 
turpações do estudo das raças humanas, e principalmente com o intuito de classificá-las hierarquicamente que surgiu o racismo".

De acordo com o artigo $1^{\circ}$. da Convenção Internacional sobre a Eliminação de Todas as Formas de Discriminação Racial, a expressão “discriminação racial" abrange:

[...] toda distinção, exclusão, restrição ou preferência baseada em raça, cor, descendência ou origem nacional ou étnica que tenha por objeto ou resultado anular ou restringir o reconhecimento, gozo ou exercício em um mesmo plano (em igualdade de condição) de direitos humanos e liberdades fundamentais nos campos político, econômico, social, cultural ou em qualquer outro campo da vida pública. ${ }^{28}$

Assim, diante da existência de perseguições por motivos raciais e buscando o equilíbrio nas relações internacionais e a proteção do ser humano, a ONU passou a debater o tema e estabeleceu que a perseguição de um ser humano por motivo de raça é critério para o reconhecimento do status de refugiado.

A perseguição por intolerância religiosa também é motivo capaz de ensejar o reconhecimento do status de refugiado a um indivíduo, uma vez que afronta a liberdade de religião, vista como fenômeno ancorado numa fé em algo transcendente, e de culto, isto é, a liberdade de praticar determinada religião, manifestada por meio de símbolos e ritos.

Já a nacionalidade seria o vínculo jurídico-político existente entre o indivíduo e determinado Estado, do qual decorrem diversos direitos e obrigações recíprocas. ${ }^{29}$ Nesse sentido, o ACNUR também promove a

${ }^{28}$ ORGANIZAÇÃO DAS NAÇÕES UNIDAS. Convenção Internacional sobre a Eliminação de Todas as Formas de Discriminação Racial, 1968. Disponível em: $<$ http://www2.camara.leg.br/atividade-legislativa/comissoes/comissoes-permanentes/cdhm/comite-brasileiro-de-direitos-humanos-e-politica-externa/ConvIntElimTodForDiscRac.html>. Acesso em: 08/10/2017.

29 PORTELA, Paulo Henrique Gonçalves. Direito internacional público e privado: incluindo noções de direitos humanos e direito comunitário, 7. ed. Salvador: Juspodivm, 2015, p. 287. 
proteção das pessoas destituídas de nacionalidade ou apátridas, destacando-se o disposto no já citado artigo XV da Declaração Universal dos Direitos Humanos de 1948.

Quanto ao pertencimento a determinado grupo social, vale destacar que se trata de critério sem definição precisa, de modo que proporciona uma maior abrangência do conceito de refugiado. Contudo, pode-se afirmar que pertencer a determinado grupo social significa o reconhecimento de um sujeito como integrante de um subgrupo da comunidade, ${ }^{30}$ tomando a título de exemplo a discriminação sofrida pela população negra.

Por fim, como último critério clássico capaz de ensejar a concessão de refúgio, tem-se a opinião política ou pública, pautada no direito à liberdade de expressão e pensamento e consagrada pelo artigo XIX da Declaração Universal dos Direitos Humanos.

Além desses critérios, Érika Pires Ramos ${ }^{31}$ afirma serem três os elementos necessários à definição de refúgio: a perseguição, o bem fundado temor ou justo temor e a extraterritorialidade. A existência de perseguição pode ser resumida na provável e possível lesão à vida ou à liberdade individual, ou seja, a ameaça à proteção da dignidade da pessoa humana. ${ }^{32} \mathrm{O}$ bem fundado temor ou justo temor seria averiguado por meio de condições objetivas do Estado de proveniência do solicitante e a relação dessas com cada indivíduo e, por fim, a extraterritorialidade é o fato de o solicitante se encontrar fora de seu país de origem ou de residência.

\subsection{Refugiados ambientais: Novos critérios para a con- cessão de Refúgio}

Com efeito, a Convenção da ONU de 1951 e o Protocolo de 1967 formam a base positiva universal do Direito Internacional dos Refugiados. Contudo, a proteção aos refugiados também foi ampliada em contextos regionais, conforme exemplos que serão abordados a seguir.

$30 \quad$ JUBILUT, Liliana Lyra. Op. cit., p. 132.

31 RAMOS, Érika Pires. Op. cit., p. 105.

32 SERRAGLIO, Diogo Andreola. Op. cit. p. 82. 
Em 1969, foi aprovada a Convenção Relativa aos Aspectos Específicos dos Refugiados Africanos reconhecida pela Organização da Unidade Africana (OUA), adotando a chamada definição ampliada de refugiado, pois criou novas hipóteses ou critérios para o reconhecimento do status de refugiado com base em desastres causados pelo homem, tendo como fundamento o perigo generalizado ou problemas em uma parcela do território de um Estado. Destaca-se o inciso II do artigo $1^{\circ}$. de mencionado diploma:

O termo refugiado aplica-se também a qualquer pessoa que, devido a uma agressão, ocupação externa, dominação estrangeira ou a acontecimentos que perturbem gravemente a ordem pública numa parte ou na totalidade do seu país de origem ou do país de que tem nacionalidade, seja obrigada a deixar o lugar da residência habitual para procurar refúgio noutro lugar fora do seu país de origem ou de nacionalidade.

Outro documento importante que ampliou a definição de refugiado foi a Declaração de Cartagena, de 1984, adotada no Colóquio sobre Proteção Internacional dos Refugiados na América Central, México e Panamá, cujo texto dispõe que:

[...] a definição ou o conceito de refugiado recomendável para sua utilização a região é o que, além de conter os elementos da Convenção de 1951 e do Protocolo de 1967, considere também como refugiados as pessoas que tenham fugido dos seus países porque a sua vida, segurança ou liberdade tenham sido ameaçadas pela violência generalizada, a agressão estrangeira, os conflitos internos, a violação maciça dos direitos humanos ou outras circunstâncias que tenham perturbado gravem ente a ordem pública.

Com efeito, a inovação mais relevante apresentada por ambos os documentos já citados é caracterizada pela introdução da violência ge- 
neralizada ou violação maciça de direitos humanos como motivo para o reconhecimento do status de refugiado a determinado indivíduo, sendo um critério deveras flexível, que busca corrigir as limitações dos documentos antecedentes.

Por sua vez, a Declaração de São José da Costa Rica sobre Refugiados e Pessoas Deslocadas, de 1994, reafirmou os princípios contidos na Declaração de Cartagena, que previa definição de refúgio amplo, abarcando aqueles que abandonam seus territórios de origem ou residência em razão de violação de garantias fundamentais, conflitos internos, ofensivas estrangeiras ou situações que abalem a ordem pública. ${ }^{33}$

Contudo, o alargamento da definição de refugiado proporcionada pelos documentos Americano e Africano não se mostrou, por óbvio, suficiente para proporcionar a plena proteção de novas categorias de refugiados, uma vez que os documentos internacionais contendo normas de proteção humanitária, em que pese serem considerados por alguns doutrinadores como jus cogens e contar com sanções internacionais para a sua violação, ainda dependem da vontade dos Estados em efetivá-los. ${ }^{34}$

Nesse contexto, destaca-se o surgimento de debate acerca da proteção dos chamados Refugiados Ambientais. É inviável, contudo, o enquadramento dessa nova categoria de refugiados nos critérios clássicos previstos pela Convenção de 1951 e pelo Protocolo de 1967, uma vez que a devastação do meio ambiente não pode ser qualificada como persecução ou outro motivo legal que configure hipótese de refúgio.

Sendo assim, internacionalmente, não haveria como enquadrar a categoria "Refugiados Ambientais", nos critérios clássicos para a concessão de refúgio, ficando tais indivíduos sujeitos às normas atinentes à migração em geral ou eventual enquadramento em dispositivos de proteção regional a refugiados como a Declaração de São José da Costa Rica sobre Refugiados e Pessoas Deslocadas, de 1994, que prevê

33 Outros documentos internacionais relevantes sobre o tema seriam: a Declaração de São José sobre Refugiados e Pessoas Deslocadas, a Declaração e Plano de Ação do México e a Declaração de Brasília Sobre a Proteção de Refugiados e Apátridas no Continente Americano.

34 JUBILUT, Liliana Lyra. Op. cit., p. 165. 
a hipótese de concessão de refúgio em caso de "violação maciça dos direitos humanos" ou "outras circunstâncias que tenham perturbado gravemente a ordem pública".

Com efeito, a situação envolvendo os refugiados ambientais, isto é, pessoas obrigadas a se deslocar em razão de infortúnios ambientais aqui entendidos como desastres naturais ou mudanças climáticas, intensificados ou não pela ação humana - pode se tornar uma das principais crises vividas pela humanidade, uma vez que o número de indivíduos deslocados de seu local de origem em razão dos efeitos das mudanças climáticas tende a crescer nas próximas décadas. ${ }^{35}$ Consoante o International Displacement Monitoring Center, no período entre 2008 e 2013, a média anual de deslocados ambientais no globo era de 27 milhões de pessoas e, em 2015, registraram-se cerca de 19,2 milhões de novos deslocamentos dessa categoria. ${ }^{36}$

Conforme Kälin e Schrepfer, ${ }^{37}$ podem ser considerados como cenários que ensejam deslocamentos ambientais forçados:

1. Desastres Repentinos, tais como inundações, tempestades de vento (furacões/tufões/ciclones) ou deslizamentos de terra causados por fortes chuvas podem provocar grandes deslocamentos: as pessoas são evacuadas ou deixam seus lares antes dos desastres ou precisam deixar seus lares devido à destruição de suas casas, infraestrutura e serviços.

35 Nesse sentido, o Programa das Nações Unidas para o Meio Ambiente estima que, aproximadamente 4,5 bilhões de hectares ao redor do globo, isto é, 35\% da superfície de terras secas do planeta, já se encontram em processo de desertificação (RAIOL, 2009).

36 Traduzido a partir de " 19.2 million new displacements by disasters in 113 countries in 2015". Disponível em: http://www.internal-displacement.org/globalreport2016/\#ongrid03. Acesso em 12 out. 2017.

37 Apud LUCHINO, María Mercedes Rodríguez Fontán; RIBEIRO, Wagner Costa. Refugiados ambientais e a atuação do ACNUR como organismo internacional de proteção. Revista Eletrônica do Curso de Direito da UFSM, Santa Maria, RS, v. 11, n. 3, p. 890-914, out. 2016. ISSN 1981-3694. Disponível em: $<\underline{\text { https://periodicos. }}$ ufsm.br/revistadireito/article/view/22071/pdf>. Acesso em 07/10/2017. 
2. Processos de Lenta Degradação Ambiental causados pelo aumento do nível do mar, aumento de salinização dos solos, efeitos de longa duração derivados de recorrentes inundações, desgelo das calotas do Polo Norte, assim como as secas e a desertificação e outras formas de redução dos recursos hídricos, são previstos como impactos negativos em longo prazo da mudança climática.

3. Os Pequenos Estados Insulares com terras baixas representam um caso especial dos desastres de evolução lenta. Como consequência do aumento do nível do mar e de sua topografia de baixa altitude, estas áreas podem se tornar cada vez mais inabitáveis, o que provoca a emigração a outros países, as pessoas perdem a fé de que haja um futuro para elas em sua terra natal. A degradação ambiental será um processo muito lento.

4. Como consequência da mudança climática, os governos designam áreas proibidas de serem habitadas por pessoas.

5. Por último, os sérios distúrbios da ordem pública, a violência ou inclusive conflitos armados que perturbam gravemente, podem ser provocados, ao menos parcialmente, pela diminuição dos recursos essenciais devido à mudança climática (como a água, as terras de cultivo ou pastos).

Assim, pode-se estabelecer que qualquer mudança física, biológica ou química de um ecossistema, apta a torná-lo inadequado para a manutenção da vida humana, temporária ou definitivamente, pode ser considerada como perturbação ambiental capaz de ensejar o enquadramento de um indivíduo que sofreu com tais modificações como refugiado.

Por sua vez, Karla Hatrick ${ }^{38}$ afirma que seriam cinco as principais causas de refúgio ambiental, sendo elas: 1) a degradação da terra agricultável; 2) os desastres ambientais; 3) destruição de ambientes pela

38 Apud DERANI, Cristiane. Refugiados ambientais. Dicionário de Direitos Humanos. Disponível em: http://escola.mpu.mp.br/dicionario/tiki-index.php?page=Refugiado+Ambiental. Acesso em: 24 abr. 2018. 
guerra; 4) deslocamento involuntário na forma de reassentamento; e 5) as mudanças climáticas.

Importante mencionar que, em 2005, cientistas se reuniram em Limoges, na França, e elaboraram um documento chamado Apelo de Limoges, o qual apresentou as bases legais para uma posterior institucionalização dos refugiados ambientais, definindo-os como "indivíduos, famílias e comunidades que enfrentam uma ruptura aguda ou gradual de seu ambiente natural, afetando, inevitavelmente, as condições básicas de sobrevivência e forçando-os, em face da situação de emergência, a deixar seus locais habituais de residência, conduzindo-os à reinstalação ou reassentamento em local diverso". ${ }^{39}$

Consoante Claro, ${ }^{40}$ fala-se ainda na existência de três grupos distintos de refugiados ambientais:

i) refugiados ambientais lato sensu, correspondente a todo e qualquer migrante influenciado não exclusiva, mas majoritariamente por alterações ambientais de vulto (EL-HINNAWI, 1985); ii) refugiados do clima, para aqueles migrantes forçados exclusivamente em decorrência da mudança e variabilidade climática abruptas (COLLECTIF ARGOS, 2010); e iii) refugiados da conservação, relativo àquelas pessoas que foram forçadas a deixar sua morada habitual em razão da criação de uma área de preservação ambiental ou similar, mas que necessariamente implique migração humana como efeito direto de políticas públicas - vale afirmar que a maior parte dos refugiados da conservação é composta por comunidades tradicionais, embora não apenas por estas. ${ }^{41}$

9 SERRAGLIO, Diogo Andreola. Op. cit., p. 99.

40 CLARO, Carolina de Abreu Batista. Op. cit., p. 40.

41 A expressão "refugiados ambientais climáticos" designaria, para Serraglio (Op. cit.), exclusivamente as pessoas que se deslocam, voluntária ou forçadamente, de modo permanente ou temporário, em virtude de mudanças climáticas ocasionadas pelo aquecimento global, isto é, oriundas da ação humana, excluindo-se qualquer tipo de degradação ambiental ou desastres não relacionados às atividades humanas, cujas vítimas devem ser tuteladas por meio de instituto diverso. O autor ainda propõe a restrição do conceito de "refugiado ambiental climático" para vítimas de três consequências diretas e indiscutíveis do aquecimento global, sendo elas a desertificação, o aumento do nível do mar e o derretimento das geleiras. 
Vale esclarecer, desde já, que para o presente trabalho será adotada a expressão "refugiados ambientais" em sentido amplo, abarcando as hipóteses de enquadramento elencadas por Kälin e Schrepfer. ${ }^{42}$

Destaca-se ainda a existência de outras categorias de pessoas que também não se enquadram nos critérios clássicos ou regionais de refugiados, como os chamados refugiados econômicos, isto é, "qualquer grupo perseguido em razão de rápido processo de desenvolvimento econômico verificado nas últimas décadas, sendo marginalizado por razões políticas, econômicas, sociais, culturais, assim como legais e institucionais". ${ }^{43}$ Assim, o autor defende a essencialidade da ampliação do conceito de refugiado a fim de viabilizar a tutela daqueles que se deslocam forçosamente, devendo-se realizar uma interpretação ampliativa das normas de proteção internacional para abarcar o surgimento de novas categorias como os refugiados ambientais ou econômicos.

\subsection{A situação dos refugiados no ordenamento jurídico brasileiro}

O Brasil foi o primeiro país do Cone Sul a integrar o Alto Comissariado das Nações Unidas, fazendo parte do Conselho Executivo do ACNUR desde 1958 e tendo ratificado e recepcionado a Convenção de 1951 e o Protocolo de 1967, respectivamente, em 1961 e 1972, adotando inicialmente a concepção de refugiado restrita a pessoas de origem europeia, consagrando a chamada "reserva geográfica" da Convenção de 51.

Apenas a partir da redemocratização brasileira, com o advento da Constituição Federal de 1988 e promulgação do Decreto 98.602, é que a cláusula de reserva geográfica foi retirada, possibilitando o acolhimento de refugiados de qualquer parte do globo.

O ACNUR celebrou acordo com o Brasil, em 1977, estabelecendo um escritório no Rio de Janeiro, que foi transferido para Brasília (1989). Além disso, fato importantíssimo para a atuação do ACNUR

\footnotetext{
42 Apud LUCHINO; RIBEIRO. Op. cit.

43 SERRAGLIO, Diogo Andreola. Op. cit. p. 93.
} 
em território brasileiro foi a parceria de entidades como a Cáritas Arquidiocesana, organizações sem fins lucrativos ligada à Igreja Católica e que atua mundialmente em projetos sociais, entre eles o tratamento humanitário aos refugiados em 21 países.

Em 1997, foi aprovada a Lei 9.474, que passou a regulamentar especificamente a temática dos refugiados no Brasil, adotando oficialmente definição mais ampla que a Convenção de 1951 e o Protocolo de 1967, acolhendo, além das hipóteses clássicas, pessoas em situação de vulnerabilidade por graves e generalizadas violações de direitos humanos.

Assim, o ordenamento jurídico brasileiro, no que diz respeito à tutela dos refugiados, passou a contar, além dos documentos internacionais com os quais o Brasil se comprometeu, com documentos básicos: A Constituição Federal de 1988 e a Lei 9.474/1997.

$\mathrm{O}$ texto constitucional brasileiro estabelece indiretamente os fundamentos legais para a aplicação do instituto do refúgio, sobretudo por meio do princípio da dignidade da pessoa humana, consagrado no artigo $1^{\mathrm{o}}$. da Constituição, da prevalência dos direitos humanos e da concessão de asilo como princípios relativos às relações internacionais do Brasil (art. $4^{\circ}$. , II e X).

Já a Lei 9.474/1997 trata-se de norma específica que estabeleceu os critérios e procedimento para o reconhecimento do status de refugiado e criou o Comitê Nacional para Refugiados (CONARE), órgão administrativo vinculado ao Ministério da Justiça e ao Ministério das Relações Exteriores, competente pela expedição de Resoluções Normativas acerca de questões práticas relativas aos refugiados e também competente pelo reconhecimento ou não, em primeira instância, do status de refugiado a determinado indivíduo.

Com efeito, a Lei 9.474/1997 adotou o "espírito de Cartagena", consagrando a definição ampliada de refugiados. Contudo, deve-se destacar que, em que pese mencionada definição ser mais ampla que a da Convenção de 1951 (reformada pelo Protocolo de 1967), a legislação brasileira permaneceu mais restrita que a da Declaração de Cartagena, englobando apenas pessoas que fogem de graves e generalizadas violações de direitos humanos. ${ }^{44}$

44 JUBILUT, Liliana Lyra. Op. cit. p. 190. 
Também, a legislação brasileira abarca o princípio do non-refoulement, impossibilitando a deportação do solicitante de refúgio, além de ignorar se a entrada em território brasileiro se deu de forma irregular, possibilitando que os procedimentos criminais e administrativos decorrentes de eventual entrada ilegal permaneçam suspensos até a conclusão do pedido de refúgio (art. 10, caput e $\S \S 1^{\circ}$. e $2^{\circ}$. da Lei 9.474/1997). Destaca-se que a norma brasileira assegura a proteção ao refugiado, fornecendo-lhe os meios para que possa trabalhar, estudar e exercer os mesmos direitos de qualquer cidadão estrangeiro legalizado no país (Lei n. 9.474/1997).

A lei 9.474/1997 ainda prevê os direitos e deveres dos refugiados, além de estipular as hipóteses de perda e cessação do status. Assim, caso o pedido seja negado ou se a condição de refugiado cesse, o indivíduo passa a ser tutelado pelas normas gerais de permanência de estrangeiro em território brasileiro, o que significa que a partir de novembro de 2017 essas pessoas serão tuteladas pela Lei de Migração (Lei n. 13.445/2017) e não mais pelo Estatuto do Estrangeiro.

Quanto aos refugiados ambientais, deve-se salientar que não há no ordenamento pátrio qualquer legislação que regulamente as categorias especificamente, ${ }^{45}$ em que pese o Brasil ter adotado definição ampla de refugiado, conforme Declaração de Cartagena e de São José da Costa Rica. Assim, as vítimas de deslocamento compulsório em virtude de infortúnios ambientais são enquadradas como migrantes voluntários, sujeitando-se às normas aplicadas a essa categoria, como o Estatuto do Estrangeiro ou a nova Lei da Migração.

Aliás, em que pese a nova Lei da Migração brasileira superar alguns paradigmas conservadores do Estatuto do Estrangeiro elaborado durante o período ditatorial no Brasil, a tutela de refugiados ambientais por normas aplicadas à migração em geral não condiz com a situação de vulnerabilidade daquela categoria.

45 A diferença existente entre deslocados internos e refugiados ambientais, nesse aspecto, é que aos deslocados internos se aplicam normas de proteção internacional, enquanto os refugiados ambientais não possuem qualquer regulamentação internacional específica. 


\section{Sistema INTERNACIONAL DE PROTEÇÃO AOS DIREITOS HUMA-} NOS E A TUTELA DOS REFUGIADOS AMBIENTAIS

Pelo já exposto, o presente tópico busca abordar as hipóteses existentes para a tutela de refugiados ambientais, apresentando a título de exemplo o caso dos refugiados haitianos e abordando o funcionamento do sistema internacional de proteção dos direitos humanos, em especial, o sistema interamericano e seus casos de maior relevância sobre o tema.

\subsection{O caso dos refugiados haitianos: visto humanitário no Brasil}

Com efeito, desde sua independência, quando resolveu adotar uma economia de cunho sustentável e estancar a produção de açúcar que lhe permitia competir no mercado internacional, o Haiti enfrenta uma economia estagnada, que gerou severos reflexos para o país, como as precárias condições sociais. Além disso, os impasses políticos e naturais vividos pela ilha no decorrer de sua história levaram a população haitiana à grande onda migratória vivenciada no século XXI.

De fato, desde 2010 o fluxo de haitianos que deixam o país em busca de condições mais dignas de vida em muito se intensificou, sendo o Brasil um dos destinos. Isso porque, em 2010, um terremoto de magnitude 7.2 na escala Richter atingiu o Haiti e, em apenas 35 segundos, mais de 300 mil prédios ruíram, incluindo quase todas as instituições do governo e a sede das Nações Unidas, deixando mais de 200 mil mortos (entre eles, 102 funcionários da ONU) e 1,5 milhão de desabrigados, sendo o pior já registrado nas Américas (ONU, 2017). No mesmo ano, o país também foi atingido por um surto de cólera que matou mais de 8.000 pessoas. Em 2012, sofreu com dois furacões, Issac e Sandy. Em outubro de 2016, foi atingido pelo Furacão Matthew, o qual deixou mais de 175 mil pessoas desalojadas e, em 2017, enfrentou reflexos dos Furacões Irma e Maria. 
O país caribenho é formado por uma população de aproximadamente 10.711.067 habitantes, ${ }^{46}$ contudo, estima-se ${ }^{47}$ que, em 2011, aproximadamente $10 \%$ da população do país teria emigrado, totalizando aproximadamente 1.009.400 pessoas. Ademais, de acordo com o Ministério das Relações Exteriores, apenas no período entre janeiro e setembro de 2013 ingressaram em território brasileiro cerca de oito mil haitianos, sendo mais de quinze mil desde 2010. Além disso, o Brasil é atualmente o único país do continente que adota política migratória especial de caráter humanitário para nacionais do Haiti. Segundo o Conselho Nacional de Imigração - CNIg, ${ }^{48}$ entre 2010 e 2014 foram 35.213 solicitações de refúgio dos haitianos, tendo ocorrido um aumento de $2.600 \%$ dessas solicitações nesse período.

Dado que o ordenamento jurídico brasileiro não prevê a ocorrência de desastres ambientais como critério capaz de ensejar o reconhecimento do status de refugiado a um indivíduo, a tutela aos haitianos que chegaram ao solo brasileiro logo após os eventos de 2010 se deu pelas regras gerais aplicadas aos estrangeiros, até que, posteriormente, o Estado brasileiro adotasse uma política migratória acolhedora e o Conselho Nacional de Imigração - CNIg passando, então, a reconhecer a entrada desses imigrantes por meio da concessão de um visto de permanência humanitário aos haitianos que solicitavam refúgio.

Assim, embora não tenham sido reconhecidos como refugiados, ainda que sob a vigência da Lei n. 9.474 e da Declaração de Cartagena, que apresentam definição mais abrangente que a Convenção de 1951 e o Protocolo de 1967, os haitianos conseguiram um tipo de visto de permanência humanitário dado pelo Ministério do Trabalho e Emprego e pelo Conselho Nacional de Imigração - CNIg, o qual lhes possibilitou

46 INSTITUTO BRASILEIRO DE GEOGRAFIA E ESTATÍSTICA. Haiti. Disponível em: $<$ https://paises.ibge.gov.br/\#/pt/pais/haiti/info/sintese>. Acesso em 05/12/2017.

47 Dados fornecidos pelo Projeto "Estudos sobre a Migração Haitiana ao Brasil e Diálogo Bilateral".

48 MINISTÉRIO DO TRABALHO E EMPREGO. I reunião ordinária do Conselho Nacional de Imigração. Brasília: fev. 2015. 
obter carteira de identidade e de trabalho, além de acesso aos serviços públicos de saúde e educação em território brasileiro. ${ }^{49}$

Em seguida, o Brasil adotou uma política de facilitação da entrada, por meio da concessão de vistos humanitários expedidos nas embaixadas brasileiras de Porto Príncipe, no Haiti, e de Quito, no Equador. Isso se deu, principalmente, porque o fluxo migratório se intensificou nos anos de 2011 e 2012 devido às vias ilegais de tráfico humano.

Essas vias, no entanto, caracterizam-se pela submissão dos viajantes a condições desumanas e também à exploração realizada por coiotes e autoridades, o que fragiliza ainda mais a condição dos deslocados. Sendo assim, a facilitação da entrada de haitianos pelo governo brasileiro também teve como finalidade acabar com o tráfico ilegal, proporcionando condições seguras de viagem aos refugiados.

Importante mencionar que, em novembro de 2017, a nova Lei da Migração brasileira (Lei n. 13.445/2017) revogou expressamente o antigo Estatuto do Estrangeiro e regulamentou o visto humanitário até então concedido aos migrantes haitianos. Observa-se, contudo, que, em que pese ter melhorado significativamente a condição jurídica dos imigrantes haitianos no Brasil, a legislação não reconheceu a condição de refugiado ambiental desses migrantes.

Assim, apesar de serem tratados como os demais migrantes "voluntários" ou "econômicos", não há que se falar em voluntariedade no caso dos migrantes haitianos, pois, de fato, devem ser tratados como refugiados ambientais, merecendo reconhecimento e proteção por meio de instituto específico a ser criado para a proteção de pessoas deslocadas compulsoriamente em razão de infortúnios ambientais.

49 BARBOZA, Estefânia Maria de Queiroz; FERREIRA, Priscila Andreoti. A proteção dos refugiados no Brasil e o procedimento para a concessão de refúgio. In: PRONER, Caroline; BARBOZA, Estefânia Maria de Queiroz; GODOY, Gabriel Gualano de. Migrações: Políticas e Direitos Humanos sob as perspectivas do Brasil, Itália e Espanha. Curitiba: Juruá, 2015, p. 167. 


\subsection{O Sistema Global e o Sistema Interamericano: estru- tura e funcionamento}

Mostra-se essencial para se averiguar de que modo ocorre a tutela jurídica dos refugiados, em especial refugiados ambientais, analisar como se deu o surgimento da noção contemporânea de Direitos Humanos, além de esclarecer como é estruturado e de que modo se dá o funcionamento Sistema Internacional e Interamericano de Proteção dos Direitos Humanos.

Conforme nos ensina Hannah Arendt, os direitos humanos não são um dado da natureza, mas uma invenção humana que permanece em constante processo de construção e reconstrução. ${ }^{50}$ Com efeito, a Declaração da ONU de 1948 introduziu essa concepção contemporânea de Direitos Humanos no âmbito internacional, sendo reiterada pela Declaração de Viena de 1993 e levando à internacionalização desses direitos que passaram a ser considerados essenciais ao ser humano, não apenas pelos ordenamentos jurídicos internos, mas também pela ordem internacional.

Destaca-se que tal internacionalização se deu como resposta às atrocidades vivenciadas durante a era nazista, ${ }^{51}$ uma vez que o totalitarismo gerou a ruptura da Filosofia do Direito e também dos Direitos Humanos, por meio da negação do valor da pessoa humana como valor-fonte do próprio Direito. ${ }^{52}$

Assim, a acepção contemporânea inaugurada pela Declaração de 1948 serviu como instrumento para a reconstrução dos valores e direitos do homem e como referencial ético a orientar a ordem jurídica internacional, marcado, essencialmente, pela primazia da dignidade humana e por uma pretensão de universalidade - porque busca proteger todo ser humano, em todas as épocas e todos os lugares - e indivisibilidade - porque pretende garantir direitos civis, políticos, sociais, econômicos e culturais.

Nessa conjuntura, foi delineado o Sistema Internacional de Pro-

50 Apud LAFER, Celso. Op. cit. p. 150-151.

51 PIOVESAN, Flávia. Direitos humanos e justiça internacional, 6. ed. São Paulo: Saraiva, 2015, p. 47.

52 LAFER, Celso. Op. cit., p. 150-151. 
teção dos Direitos Humanos como "vertente de um constitucionalismo global, vocacionado a proteger direitos fundamentais e a limitar o poder do Estado, mediante a criação de um aparato internacional de proteção de direitos". ${ }^{53}$

Nota-se que o Direito Internacional dos Direitos Humanos lato sensu é analisado em três vetores distintos de proteção, sendo eles: 1) o Direito Internacional dos Direitos Humanos stricto sensu, consagrado pela Declaração Universal dos Direitos Humanos de 1948; 2) o Direito Internacional Humanitário, o qual possui como foco a atuação do Comitê Internacional da Cruz Vermelha, instituição responsável pela elaboração e aplicação de normas humanitárias, como em caso de conflitos armados; e 3) o Direito Internacional dos Refugiados, formado essencialmente pelo Estatuto do ACNUR.

Oportuno mencionar que, conforme lições de Jubilut, ${ }^{54}$ o Direito Internacional dos Direitos Humanos stricto sensu ${ }^{55}$ e o Direito Internacional dos Refugiados apresentam o mesmo objeto, método, sujeitos, princípios e finalidades, ${ }^{56}$ motivo pelo qual a autora concluiu que o primeiro, por ter maior aplicabilidade e escopo de proteção, engloba as garantias do segundo.

O Brasil, por estar situado no continente americano, faz parte do Sistema Interamericano de Proteção dos Direitos Humanos (consagrado pelo Pacto de San José da Costa Rica de 1969), o qual conta, entre

53 PIOVESAN, Flávia. Op. cit., p. 47.

54 JUBILUT, Liliana Lyra. Op. cit., p. 60.

55 Especificamente quanto ao Sistema Internacional de Proteção dos Direitos Humanos stricto sensu, tem-se que este é integrado por tratados internacionais de proteção que refletem, sobretudo, a consciência ética do pós-guerra, tendo sido instituído pelo Pacto Internacional dos Direitos Civis e Políticos e o Pacto Internacional de Direitos Econômicos, Sociais e Culturais, ambos de 1966, sendo dividido em um Sistema Global e outros Sistemas Complementares, dos quais se destacam o Sistema Interamericano, o Europeu e o Africano, os quais buscam internacionalizar os direitos humanos nos planos regionais.

56 Segundo a autora, ambos buscam a proteção da pessoa humana na ordem internacional por meio de regras internacionais que visem assegurar essa proteção, possuindo como sujeitos o ser humano enquanto beneficiário e o Estado enquanto destinatário e obrigado principal, além de estarem pautados na dignidade da pessoa humana. 
os mecanismos de monitoramento e implementação dos Direitos Humanos, com a Comissão e a Corte Interamericana de Direitos Humanos.

A Comissão tem como principal função promover a observância e a proteção dos direitos humanos no continente americano, cabendo-lhe, entre outras atribuições, elaborar estudos, relatórios e recomendações aos Estados-partes acerca de medidas necessárias à proteção dos direitos previstos pela Convenção Interamericana de Direitos Humanos, além de solicitar aos governos informações acerca da implementação da Convenção e submeter relatório anual à Assembleia Geral da Organização dos Estados Americanos. ${ }^{57}$

Cabe também à Comissão examinar as comunicações encaminhadas por indivíduo, grupos de indivíduos ou entidade não governamental que denunciem violação a direito consagrado pela Convenção por algum Estado-parte, realizando juízo de admissibilidade com base nos requisitos estabelecidos no artigo 46 da Convenção, ${ }^{58}$ solicitando informações dos Estados denunciados, podendo, conforme o caso, arquivar a comunicação ou realizar investigação.

Uma vez apurada a violação a direito consagrado pela Convenção e não havendo solução amistosa com o Estado denunciado, a Comissão produzirá um relatório, do qual devem constar os fatos, conclusões sobre o caso e recomendações ao Estado-parte. Não tendo sido solucionado pelas partes dentro de três meses, o caso pode ser encaminhado pela Comissão à Corte Interamericana de Direitos Humanos, órgão jurisdicional do sistema regional que possui competência consultiva e contenciosa, sendo composto por juízes nacionais de países membros da OEA e eleitos pelos Estado-partes.

57 PIOVESAN, Flávia. Op. cit., p. 143.

58 Artigo 46. "1. Para que uma petição ou comunicação apresentada de acordo com os artigos 44 ou 45 seja admitida pela Comissão, será necessário: a. que hajam sido interpostos e esgotados os recursos da jurisdição interna, de acordo com os princípios de direito internacional geralmente reconhecidos; $b$. que seja apresentada dentro do prazo de seis meses, a partir da data em que o presumido prejudicado em seus direitos tenha sido notificado da decisão definitiva; c. que a matéria da petição ou comunicação não esteja pendente de outro processo de solução internacional; e d. que, no caso do artigo 44, a petição contenha o nome, a nacionalidade, a profissão, o domicílio e a assinatura da pessoa ou pessoas ou do representante legal da entidade que submeter a petição.” 
Quanto à atribuição consultiva da Corte, Piovesan ${ }^{59}$ destaca que "qualquer membro da OEA — parte ou não da Convenção - pode solicitar o parecer da Corte relativamente à interpretação da Convenção ou de qualquer outro tratado relativo à proteção dos direitos humanos aplicável aos Estados americanos". Além disso, a Corte pode apresentar parecer acerca da compatibilidade entre legislações nacionais e instrumentos internacionais, efetuando, assim, o chamado controle da convencionalidade das leis.

Já no plano contencioso, destaca-se que a competência da Corte abrange, como já mencionado, o exame de casos que envolvam violação de direito protegido pela Convenção por parte de um Estado-parte. Destaca-se que para que haja julgamento pela Corte é essencial que os Estados tenham reconhecido a jurisdição da Corte por meio da Convenção de 1969.

Caso reconheça a violação a direito previsto na Convenção, a Corte determinará ao Estado a adoção de medidas necessárias à restauração do direito violado, podendo, inclusive, condenar o Estado a pagar uma compensação à vítima, decisão essa considerada como título executivo perante o ordenamento jurídico interno, já que as decisões das Cortes têm força jurídica vinculante e obrigatória, devendo o Estado realizar seu cumprimento imediato. ${ }^{60}$

Nota-se que a Corte Interamericana de Direitos Humanos poderá analisar somente casos submetidos pela Comissão Interamericana ou por algum Estado-parte, não havendo previsão de legitimidade de indivíduos, os quais poderão apresentar suas denúncias perante a Comissão, nos termos dos artigos 46, 48 e 61 da Convenção Americana.

Quanto à análise de casos envolvendo refugiados ambientais frente ao Sistema Interamericano, vale destacar que a Declaração de São José da Costa Rica, sobre Refugiados e Pessoas Deslocadas, de 1994, reafirmou os princípios contidos na Declaração de Cartagena permitindo, assim, incluir os refugiados ambientais ao proteger aqueles que

59 PIOVESAN, Flávia. Direitos humanos e direito constitucional internacional, 15. ed. São Paulo: Saraiva, 2015, p. 351.

60 IBIDEM. 
se deslocam em virtude de "grave e generalizada violação de direitos humanos" ou "situações que abalam a ordem pública".

Contudo, conforme destaca Serraglio, ${ }^{61}$ "em razão dos embates políticos e econômicos na sociedade contemporânea, ainda parece haver pouco espaço para a utilização e devida aplicabilidade desse conceito [refugiados ambientais climáticos] no Sistema Interamericano de Proteção dos Direitos Humanos".

Em termos de tutela jurídica de refugiados ambientais climáticos, especificamente, isto é, aqueles deslocados em virtude de mudanças climáticas decorrentes do processo de aquecimento global, destacam-se os casos de Tuvalu, Maldivas e Shishmaref, nos quais o ambiente se tornou ou se tornará inabitável em decorrência dos efeitos do aquecimento global o que ocasionou o surgimento de milhares de refugiados.

O primeiro caso envolvendo refugiados ambientais climáticos, intitulado Inuits x Estados Unidos da América, ocorreu no Sistema Interamericano de Direitos Humanos. ${ }^{62}$ Já o caso de maior relevância no Sistema Americano de Direitos Humanos envolvendo a temática dos refugiados diz respeito ao processo n. 10.675, envolvendo refugiados haitianos que foram impedidos de entrar nos Estados Unidos - EUA, pois o país impediu que os barcos que transportavam os refugiados entrassem em seu mar territorial alegando que, nessa hipótese, não haveria ofensa ao princípio do non-refoulement, uma vez que os refugiados sequer chegaram ao território americano. A Comissão Interamericana de Direitos Humanos apresentou parecer favorável aos refugiados haitianos, concluindo que os EUA, de fato, violaram o princípio do non-refoulement, entre os direitos essenciais à pessoa humana, contudo, a decisão não se mostrou efetiva diante da histórica abstenção de referido país na proteção internacional dos Direitos Humanos. ${ }^{63}$

${ }_{61}$ SERRAGLIO, Diogo Andreola. Op. cit., p. 128.

62 RAIOL, Ivanilson Paulo Corrêa. Ultrapassando fronteiras: a proteção jurídica dos refugiados ambientais, 2009, 313s. Tese (Doutorado) - Universidade Federal do Pará, Instituto de Ciências Jurídicas, Belém, 2009. Programa de Pós-Graduação em Direito. Disponível em: < http://repositorio.ufpa.br/jspui/handle/2011/7284 > . Acesso em: 12/10/2017, p. 192.

${ }^{63}$ JUBILUT, Liliana Lyra. Op. cit., p. 165. 
Isso porque, as decisões do Sistema Interamericano, assim como a proteção do Direito Internacional Humanitário, como já mencionado neste artigo, não obstante ser considerada jus cogens por alguns doutrinadores e contar com sanções internacionais para a sua violação, dependem da vontade dos Estados ou das partes em conflito para que haja o pleno cumprimento.

Assim, a precária proteção jurídica internacional dada aos Refugiados ambientais somada ao irrisório número de ações sobre o tema julgadas pelo Sistema Interamericano demonstram que a tutela dessa categoria de deslocados necessita de aprimoramento, sobretudo por meio da ampliação da definição de refugiado no âmbito das Nações Unidas, dos Sistemas Regionais e das legislações internas dos Estados-partes.

Além disso, visto que a problemática envolvendo refugiados ambientais pode vir a ser uma das maiores crises a serem enfrentadas nos próximos séculos, conforme mencionado inicialmente neste artigo, mostra-se essencial um maior comprometimento dos Estados na efetivação dos tratados e convenções internacionais acerca da proteção dos direitos humanos das pessoas deslocadas e também no cumprimento das decisões do Sistema Internacional de proteção.

\section{CONSIDERAÇões FINAIS}

$\mathrm{O}$ artigo demonstrou que o refúgio se estabeleceu como instituto apenas em 1921, tendo como marco a Liga das Nações, e só foi regulamentado, em 1951, com a elaboração da Convenção Relativa ao estatuto dos Refugiados de 1951, dando origem ao Alto Comissariado das Nações Unidas para os Refugiados - ACNUR. Além disso, a definição clássica de refúgio, a qual ainda permanece vigente na ordem internacional, protege qualquer pessoa que se encontre fora de seu país de origem e não pode ou não quer regressar ao mesmo "por causa de fundados temores de perseguição devido à sua raça, religião, nacionalidade, associação a determinado grupo social ou opinião política [...] conflitos armados, violência generalizada e violação massiva dos direitos humanos". ${ }^{64}$

${ }_{64}$ ACNUR. Op. cit., 2017a. 
Demonstrou-se também que essa proteção foi ampliada em contextos regionais, como pela Convenção Relativa aos Aspectos Específicos dos Refugiados Africanos adotada pela Organização da Unidade Africana (OUA) e Declaração de Cartagena, de 1984, adotada no Colóquio sobre Proteção Internacional dos Refugiados na América Central, México e Panamá.

Concluiu-se que, em que pese o alargamento da definição de refugiado proporcionada por documentos regionais, deve-se observar que o Direito Internacional ainda não fornece proteção a pessoas deslocadas em decorrência de desastres ou mudanças ambientais. Da mesma maneira, não há no ordenamento jurídico brasileiro qualquer legislação que regulamente essa categoria especificamente. Assim, os refugiados ambientais dependem, sobretudo, da proteção do Direito Internacional dos Direitos Humanos stricto sensu e do Direito Internacional dos Refugiados.

Nesse contexto, analisou-se o caso dos refugiados haitianos como exemplo de refugiados ambientais que, não recebendo proteção específica, ficam sujeitos às normas aplicadas aos migrantes voluntários e políticas governamentais, como a adotada pelo Brasil, após os eventos ocorridos na ilha caribenha em 2010, que geraram o surgimento de um grande movimento emigratório de haitianos.

Além disso, em que pese bem-sucedida a política humanitária adotada pelo governo brasileiro e as alterações da nova Lei da Migração, não há que se falar em voluntariedade no caso dos migrantes haitianos, pois, de fato, devem ser tratados como refugiados ambientais, merecendo reconhecimento e proteção por meio de instituto específico a ser criado para a proteção de pessoas deslocadas compulsoriamente em razão de infortúnios ambientais.

Analisou-se também o Sistema Internacional de Proteção dos Direitos Humanos, em especial o sistema Interamericano, como via possível para que os refugiados ambientais alcancem a proteção de seus direitos, a exemplo do caso n. 10.675, envolvendo refugiados haitianos que foram impedidos de entrar nos Estados Unidos - EUA.

Por fim, concluiu-se que a proteção jurídica internacional e interna (brasileira) dada aos Refugiados ambientais ainda é muito precária. 
Além disso, é irrisório o número de ações sobre o tema julgadas pelo Sistema Interamericano, demonstrando-se que a tutela dos refugiados ambientais demanda, com urgência, a ampliação dos critérios clássicos para a concessão do Refúgio, tanto no âmbito das Nações Unidas, como nos Sistemas Regionais e nas legislações internas dos Estados, o que incluiu uma reforma na legislação brasileira.

Além disso, visto que a problemática envolvendo refugiados ambientais pode vir a ser uma das maiores crises a serem enfrentadas nos próximos séculos, conforme mencionado inicialmente neste artigo, mostra-se essencial um maior comprometimento dos Estados na efetivação dos tratados e convenções internacionais acerca da proteção dos direitos humanos das pessoas deslocadas e também no cumprimento das decisões do Sistema Internacional de proteção.

\section{REFERÊNCIAS}

ALTO COMISSARIADO DAS NAÇÕES UNIDAS PARA REFUGIADOS. Breve histórico do ACNUR. Disponível em: $<$ http://www.acnur.org/portugues/informacao-geral/breve-historico-do-acnur/>. Acesso em: 5/12/2017a.

ALTO COMISSARIADO DAS NAÇÕES UNIDAS PARA REFUGIADOS. Deslocados internos. Disponível em: <http://www.acnur.org/portugues/ quem-ajudamos/deslocados-internos/ Acesso em: 6 out. 2017b.

ALTO COMISSARIADO DAS NAÇÕES UNIDAS PARA REFUGIADOS. Estatísticas. Disponível em: $<$ http://www.acnur.org/portugues/recursos/estatisticas/>. Acesso em: 6/10/2017c.

ALTO COMISSARIADO DAS NAÇÕES UNIDAS PARA REFUGIADOS. Quem são e onde estão os apátridas. Disponível em: $<$ http://www.acnur.org/ portugues/quem-ajudamos/apatridas/quem-sao-e-onde-estao-os-apatridas/>. Acesso em: 6/10/2017d.

ALTO COMISSARIADO DAS NAÇÕES UNIDAS PARA REFUGIADOS. Refugiados. Disponível em: <http://www.acnur.org/portugues/quem-ajudamos/refugiados/>. Acesso em: 6/10/2017e. 
ARAÚJO, Nádia (coord.); ALMEIDA, Guilherme Assis de (coord.). O direito internacional dos refugiados: uma perspectiva brasileira. Rio de Janeiro: Renovar, 2011.

BARBOZA, Estefânia Maria de Queiroz; FERREIRA, Priscila Andreoti. A proteção dos refugiados no Brasil e o procedimento para a concessão de refúgio. In: PRONER, Caroline; BARBOZA, Estefânia Maria de Queiroz; GODOY, Gabriel Gualano de. Migrações: Políticas e Direitos Humanos sob as perspectivas do Brasil, Itália e Espanha. Curitiba: Juruá, 2015, p. 167.

BRASIL. Ministério do Trabalho e Emprego. I reunião ordinária do Conselho Nacional de Imigração. Brasília: fev. 2015.

CLARO, Carolina de Abreu Batista. Refugiados ambientais: mudanças climáticas, migrações internacionais e governança global, 2012, 113s., il. Dissertação (Mestrado em Desenvolvimento Sustentável) - Universidade de Brasília, Brasília, 2012.

DERANI, Cristiane. Refugiados ambientais. Dicionário de Direitos Humanos. Disponível em: http://escola.mpu.mp.br/dicionario/tiki-index. php?page=Refugiado+Ambiental. Acesso em: 24 abr. 2018.

FARENA, Maritza Natalia Ferretti Cisneros. Direitos humanos dos migrantes. Curitiba: Juruá, 2012.

FERNANDES, Duval (coord.). Projeto "estudos sobre a migração haitiana no Brasil e diálogo bilateral”, Belo Horizonte: fev. 2014. Disponível em: $<$ http://obs.org.br/cooperacao/download/34_7a099729afe2d4aaf109503e6d af3908>. Acesso em: 5 dez. 2017.

INSTITUTO BRASILEIRO DE GEOGRAFIA E ESTATÍSTICA. Haiti. Disponível em: <https://paises.ibge.gov.br/\#/pt/pais/haiti/info/sintese>. Acesso em: 5/12/2017.

JUBILUT, Liliana Lyra. O direito internacional dos refugiados e sua aplicação no ordenamento jurídico brasileiro. São Paulo: Método, 2007.

LAFER, Celso. A reconstrução dos direitos humanos: um diálogo com o pensamento de Hannah Arendt. São Paulo: Companhia das Letras, 1988.

LUCHINO, María Mercedes Rodríguez Fontán; RIBEIRO, Wagner Costa. Refugiados ambientais e a atuação do ACNUR como organismo interna- 
cional de proteção. Revista Eletrônica do Curso de Direito da UFSM, Santa Maria, RS, v. 11, n. 3, p. 890-914, out. 2016. ISSN 1981-3694 Disponível em: < https://periodicos.ufsm.br/revistadireito/article/view/22071/pdf $>$. Acesso em: 7 out. 2017.

ORGANIZAÇÃO DA UNIDADE AFRICANA. Convenção relativa aos aspectos específicos dos refugiados africanos, 1969. Disponível em: <http:// www.refugiados.net/cid_virtual_bkup/asilo2/2couaapr.html>. Acesso em: 5 dez. 2017.

ORGANIZAÇÃO DAS NAÇÕES UNIDAS. Convenção Internacional sobre a Eliminação de Todas as Formas de Discriminação Racial, 1968. Disponível em: <http://www2.camara.leg.br/atividade-legislativa/comissoes/ comissoes-permanentes/cdhm/comite-brasileiro-de-direitos-humanos-e-politica-externa/ConvIntElimTodForDiscRac.html>. Acesso em: 8/10/2017.

ORGANIZAÇÃO DAS NAÇÕES UNIDAS. Convenção relativa ao estatuto dos refugiados, 1951. Disponível em: <http://www.acnur.org/fileadmin/ scripts/doc.php?file=fileadmin/Documentos/portugues/BDL/Convencao_relativa_ao_Estatuto_dos_Refugiados $>$. Acesso em: 5/12/2017.

ORGANIZAÇÃO DAS NAÇÕES UNIDAS. Declaração Universal dos Direitos Humanos. Disponível em: <http://www.direitoshumanos.usp.br>. Acesso em: 8/10/2017.

PIOVESAN, Flávia. Direitos humanos e direito constitucional internacional, 15. ed. São Paulo: Saraiva, 2015a.

PIOVESAN, Flávia. Direitos humanos e justiça internacional, 6. ed. São Paulo: Saraiva, 2015b.

PORTELA, Paulo Henrique Gonçalves. Direito internacional público e privado: incluindo noções de direitos humanos e direito comunitário, 7. ed. Salvador: Juspodivm, 2015.

RAIOL, Ivanilson Paulo Corrêa. Ultrapassando fronteiras: a proteção jurídica dos refugiados ambientais, 2009, 313s. Tese (Doutorado) - Universidade Federal do Pará, Instituto de Ciências Jurídicas, Belém, 2009. Programa de Pós-Graduação em Direito. Disponível em: <http://repositorio.ufpa.br/jspui/ handle/2011/7284>. Acesso em: 12/10/2017. 
RAMOS, Érika Pires. Refugiados ambientais: em busca de reconhecimento pelo direito internacional, 2011. Tese (Doutorado em Direito Internacional) - Faculdade de Direito, University of São Paulo, São Paulo, 2011. doi: 10.11606/T.2.2011.tde-10082012-162021. Acesso em: 2018-02-26.

SERRAGLIO, Diogo Andreola. A proteção dos refugiados ambientais pelo direito internacional: Uma leitura a partir da Teoria da Sociedade de Risco. Curitiba: Juruá, 2014.

\section{SOBRE AS AUTORAS}

\section{Cátia Rejane Mainardi Liczbinski}

Doutora em Ciências Sociais pela UNISINOS. Mestre em Direito, Desenvolvimento, Gestão e Cidadania pela Universidade Regional do Noroeste do Estado do Rio Grande do Sul. Especialista em Direito Privado e Professora nos cursos de Direito, Relações Internacionais e Administração. Professora da Universidade Regional de Blumenau - FURB

E-mail: catia_sarreta@hotmail.com

\section{Leura Dalla Riva}

Acadêmica de Direito da Universidade Regional de Blumenau - FURB. Estagiária do Ministério Público Federal na Procuradoria da República do Município de Blumenau/SC. Pesquisadora no Grupo de Estudos em Teorias da Justiça - GETJUS/FURB. Pesquisadora no Núcleo de Estudos em Constitucionalismo, Internacionalização e Cooperação - CONSTINTER/FURB. Pesquisadora da Academia Brasileira de Direito Constitucional - ABDConst no projeto "O patrimônio comum do constitucionalismo democrático e a contribuição da América Latina".

E-mail: leura-d@hotmail.com

Submetido em: 3-5-2018

Aceito em: 9-7-2018 